\title{
Corrosion behavior of austempered ductile iron (ADI) in iron ore slurry
}

\author{
M. Pooja ${ }^{1}$, V. Vijeesh ${ }^{2 *}$, A. O. Surendranathan ${ }^{3}$, K. R. Udupa ${ }^{3}$ and K. G. Samuel ${ }^{1}$ \\ ${ }^{I}$ Department of Metallurgy, Amal Jyothi College of Engineering, Kanjirappally, Kerala. INDIA \\ ${ }^{2}$ Department of Mechanical Engineering, Sree Buddha College of Engineering, Patoor, Alappuzha,INDIA \\ ${ }^{3}$ Department of Metallurgical and Materials engineering, National Institute of Technology Karnataka, Surathkal, INDIA \\ ${ }^{*}$ Corresponding author, E-mail:: vijeesh3@gmail.com, Phone +919035107075
}

\begin{abstract}
Corrosion behavior of austempered ductile iron (ADI) in iron ore slurry was studied as a function of the microstructure developed by austempering at 380 and $300^{\circ} \mathrm{C}$ for different exposure time in the slurry. The corrosion rates of the ADI balls immersed in the iron ore slurry was determined using weight loss method. It was found that the $\mathrm{pH}$ of the iron ore slurry increased with time and the corrosion behavior is also influenced by the $\mathrm{pH}$ of the slurry and the austempering treatment. The $\mathrm{ADI}$ austempered at higher temperature showed better corrosion resistance than the ones austempered at lower temperature. The complex nature of corrosion of ADI is influenced by contents of retained austenite, ferrite and the carbon content in a collective way.
\end{abstract}

Keywords: Austempered ductile iron, iron ore slurry, weight-loss method

\section{Introduction}

Austempered ductile iron (ADI) is well known for its superior wear resistance, fatigue properties and fracture toughness. Because of its wear resistance properties, the ADI has replaced many forged and cast steel components and conventional ductile iron castings. Iron ore grinding is the last and most critical stage in the process of comminution as it governs the economy and efficiency of ore processing since it attributes to 40-50\% of the total cost of ore processing (Rao and Natarajan, 1991; Jain, 2001). The particle size is reduced by a combination of impact and abrasion using hard steel balls. The major problem in ore grinding is the wear of the grinding media balls and hence it becomes important to select a material which offers best wear resistance (Siddan, 2014). One of the main problems with ball mill is corrosion of the media balls (Eric et al., 2010; Afolabi, 2011). It was reported that (Prasanna et al., 2009, Afolabi 2011; Arunima Banerjee et al., 2013) austempering affects microstructure and corrosion properties of ductile iron. It was also reported that the percentage of retained austenite in ADI influences its corrosion behavior, higher the percentage of retained austenite lower the corrosion rate (Cheng-Hsun et al., 2010). In general single phases such as ferrite, austenite and martensite perform better in corrosive atmospheres than two phase mixtures such as pearlite, bainite and tempered martensite (Muthukumaraswamy et al., 1990). The present study is an attempt to study the corrosion resistance of ADI grinding balls with different austempering treatments in iron ore slurry using weight loss method.

\section{Experimental}

The chemical composition of the iron ore used for the study is given in the Table 1. A ball mill setup was used to prepare the iron ore slurry using the feed materials, iron ore and water. The slurry was prepared by wet grinding method in a sealed rubber lined ball mill operated $65 \mathrm{rpm}$ for an hour. A set of 200 balls of forged EN31 steel and austempered ductile iron were used as the grinding media. The ground iron ore slurry was then used as a medium to study the corrosion behavior of the ADI balls. The $\mathrm{pH}$ of the ground iron ore slurry was measured as a function of time using model EQ614 Equiptronics Digital pH Meter. 
Table 1 Chemical composition of iron ore

\begin{tabular}{|l|l|l|l|l|l|}
\hline Element & $\mathrm{Fe}_{2} \mathbf{O}_{3}$ & $\mathbf{S i O}_{\mathbf{2}}$ & Alumina & Phosphorus & Sulphur \\
\hline Composition & 94.87 & 1.7 & 1.8 & 0.07 & 0.0007 \\
\hline
\end{tabular}

The chemical composition of the ductile iron balls (dia. $25 \mathrm{~mm}$ ) is given in the Table 2. Ductile iron balls were coated with the Cu by dipping the balls into $\mathrm{CuCl}_{2}$ solution to prevent it from surface oxidation during the heat treatment. Ductile iron balls were austenitised at $900 \mathrm{C}$ for 60 minutes using a muffle silicon carbide electrical resistance furnace and quickly transferred to a molten salt bath consisting of a mixture of sodium nitrate and potassium nitrate for bainitic transformation. Then the samples were austempered at 380 and $300 \mathrm{C}$ for time durations of 30,60 and 90 minutes. The austempered samples were air cooled to room temperature.

Table 2 Chemical composition (wt $\%$ ) of grinding balls

\begin{tabular}{|l|l|l|l|l|l|l|l|l|}
\hline Material & $\mathbf{C}$ & $\mathbf{S i}$ & $\mathbf{M n}$ & $\mathbf{C r}$ & Mo & $\mathbf{S}$ & $\mathbf{P}$ & $\mathbf{M g}$ \\
\hline Ductile Iron & 3.6 & 2.8 & 0.4 & ----- & 0.3 & 0.01 & 0.01 & 0.04 \\
\hline
\end{tabular}

The corrosion behaviors of the ADI samples were determined by the conventional weight loss method using grounded iron ore slurry as the corrosion medium. For weight loss method analysis, the ADI ball samples were immersed in the grounded iron ore slurry for different time periods. The corrosion rate, $C R$, is calculated using the equation,

$$
C R=k \frac{W}{D x A x T}
$$

where, $W$ is the weight loss in the sample, $D$ is the density of the sample, $A$ is the area of the sample, $T$ is the exposure time and $k$ is a constant which depends on the units of the parameters used. Values of $k$ for different units used in the formula are given in Table 3.

Table $3 k$ values in equation (1) for different units used

\begin{tabular}{|c|c|c|}
\hline Corrosion rate unit & Units used & $k$ Value \\
\hline $\mathrm{mpy}$ & $\mathrm{W}(\mathrm{mg}), \mathrm{D}(\mathrm{g} / \mathrm{cc}), \mathrm{A}\left(\mathrm{cm}^{2}\right), \mathrm{T}(\mathrm{h})$ & 3450 \\
\hline $\mathrm{mpy}$ & $\mathrm{W}(\mathrm{mg}), \mathrm{D}(\mathrm{g} / \mathrm{cc}), \mathrm{A}\left(\mathrm{in}^{2}\right), \mathrm{T}(\mathrm{h})$ & 535 \\
\hline $\mathrm{mpy}$ & $\mathrm{W}(\mathrm{g}), \mathrm{D}(\mathrm{g} / \mathrm{cc}), \mathrm{A}\left(\mathrm{in}^{2}\right), \mathrm{T}($ days $)$ & 22,300 \\
\hline $\mathrm{mpy}$ & $\mathrm{W}(\mathrm{g}), \mathrm{D}(\mathrm{g} / \mathrm{cc}), \mathrm{A}\left(\mathrm{cm}^{2}\right), \mathrm{T}($ days $)$ & 14370 \\
\hline $\mathrm{mm} / \mathrm{year}$ & $\mathrm{W}(\mathrm{g}), \mathrm{D}(\mathrm{g} / \mathrm{cc}), \mathrm{A}\left(\mathrm{in}^{2}\right), \mathrm{T}($ days $)$ & 566 \\
\hline $\mathrm{mm} /$ year & $\mathrm{W}(\mathrm{g}), \mathrm{D}(\mathrm{g} / \mathrm{cc}), \mathrm{A}\left(\mathrm{cm}^{2}\right), \mathrm{T}(\mathrm{days})$ & 3650 \\
\hline $\mathrm{mm} /$ year & $\mathrm{W}(\mathrm{mg}), \mathrm{D}(\mathrm{g} / \mathrm{cc}), \mathrm{A}\left(\mathrm{in}^{2}\right), \mathrm{T}(\mathrm{h})$ & 1.36 \\
\hline $\mathrm{mm} /$ year & $\mathrm{W}(\mathrm{mg}), \mathrm{D}(\mathrm{g} / \mathrm{cc}), \mathrm{A}\left(\mathrm{cm}^{2}\right), \mathrm{T}(\mathrm{h})$ & 87.6 \\
\hline mpy $=$ milli-inches per year or mils per year
\end{tabular}

Metallographic examinations were carried out on the polished specimen after etching with 3\% natal solution, under the scanning electron microscope (JEOL). Quantitative information on the volume fraction of retained austenite, ferrite and the carbon content of austenite was obtained through X-ray diffraction on JEOL JDX 8P diffractometer using $\mathrm{CuK}_{\alpha}$ radiation [Cullity 1978].

\section{Results and Discussion}

In the case of ductile iron, the high carbon content causes the presence of spheroidal graphite nodules embedded in the iron matrix. Ductile iron balls were first austenitised to dissolve carbon, then quenched rapidly to the austempering temperature to avoid the formation of deleterious pearlite or martensite. When the iron balls are held at the austempering temperature nucleation and growth of acicular ferrite occurs, accompanied by rejection of carbon into the austenite. The resulting microstructure, known as "Ausferrite", consists of a mix of acicular ferrite and high carbon Austenite. 
It was reported (Rao and Putatunda, 2005; Keough and Hayrynen, 2010; Guesser et al., 2012; Janjić et al., 2016) that high temperatures ADIs (where the temperature of isothermal transformation in the range $350{ }^{\circ} \mathrm{C}-420{ }^{\circ} \mathrm{C}$ ) produce a typically upper ausferritic microstructure, which consists of broad blades of isolated ferrite. The microstructure consists of spheroidal graphite and the matrix of ausferrite needles. Typical microstructure of the high temperature and low temperature ADIs are shown Fig 1a and Figue $1 \mathrm{~b}$, respectively. At $380^{\circ} \mathrm{C}$ upper bainite with a feathery morphology was stable. At this temperature, while the amount of retained austenite decreased with increase in austempering time, ferrite content increased with time. The microstructure of low temperature ADIs (where the temperature of the isothermal transformation in the range $250{ }^{\circ} \mathrm{C}-330{ }^{\circ} \mathrm{C}$ ) showed a change in bainitic structure. At $300^{\circ} \mathrm{C}$ lower bainite with acicular morphology was observed. At this temperature also the variation of amount of retained austenite and ferrite are similar to that of the high temperature ADIs with the difference that the amount retained austenite and ferrite being less compared with high temperature ADIs.
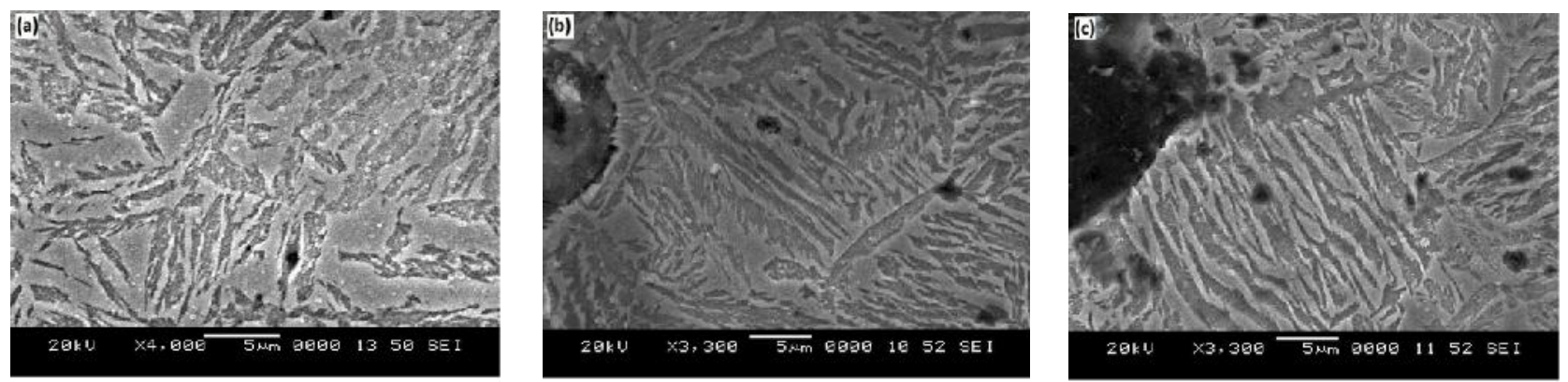

Figure 1a. Microstructure of ADI austempered at 380 C. (a) 30 mins (b) 60 mins (c) 90 mins.
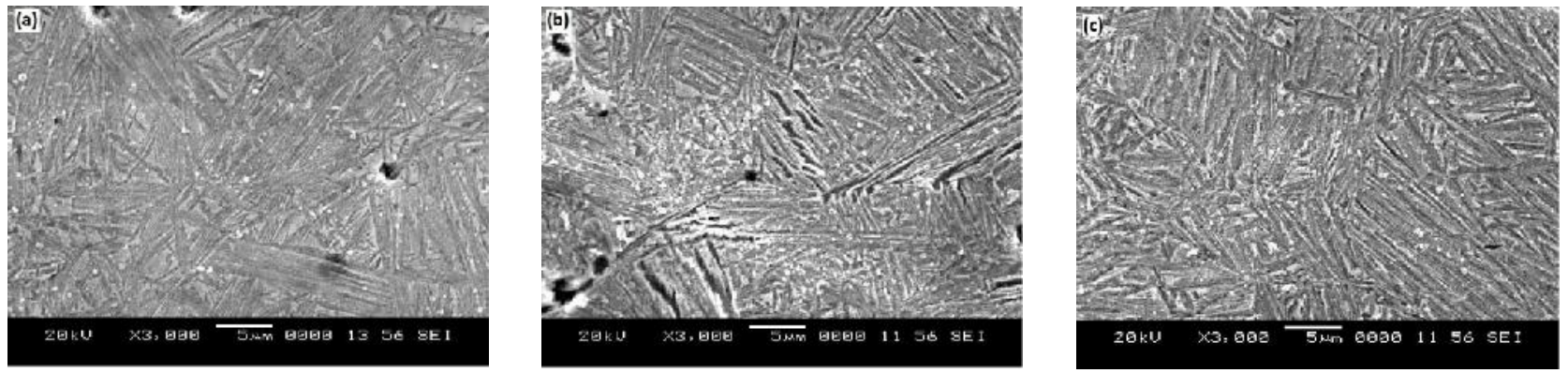

Figure 1b. Microstructure of ADI, austempered at 300 C. (a) 30 mins (b) 60 mins (c) 90 mins.

The relative amounts of austenite, ferrite and the carbon content of austenite are shown in Figure $2 \mathrm{a}$ and Figure $2 \mathrm{~b}$ for different austempering treatment. The carbon content in the retained austenite decreases with austempering time. High temperature and low temperature ADIs showed a decrease in carbon content with ageing time. At 90 minutes ageing the carbon content in the retained austenite show a larger decrease compared to that of high temperature ADI.
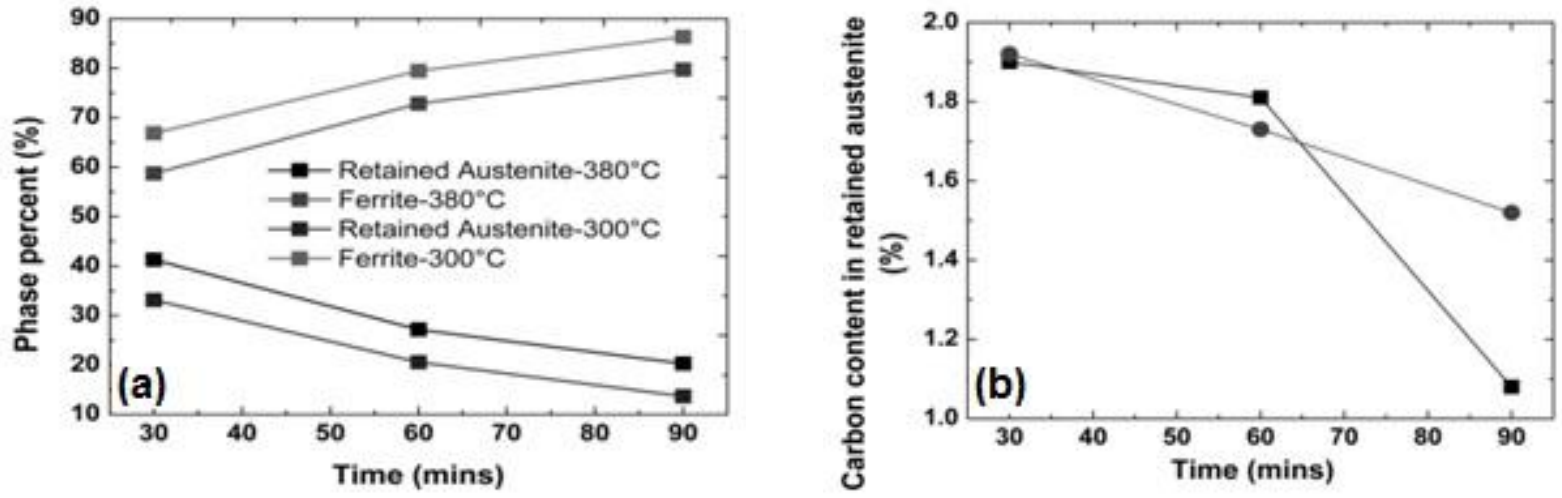

Figure 2 Volume percentage of (a) retained austenite and ferrite (b) carbon content in retained austenite by XRD analysis

Figure 3a shows the cumulative loss in weight (a measure of the degree of corrosion) occurred in different ADI sample for different time periods in the iron ore slurry. High temperature ADIs showed lower weight loss. It was also noted that the $\mathrm{pH}$ of the ground iron ore slurry increased with time in a more or less linear fashion as shown in Figure $3 \mathrm{~b}$. 

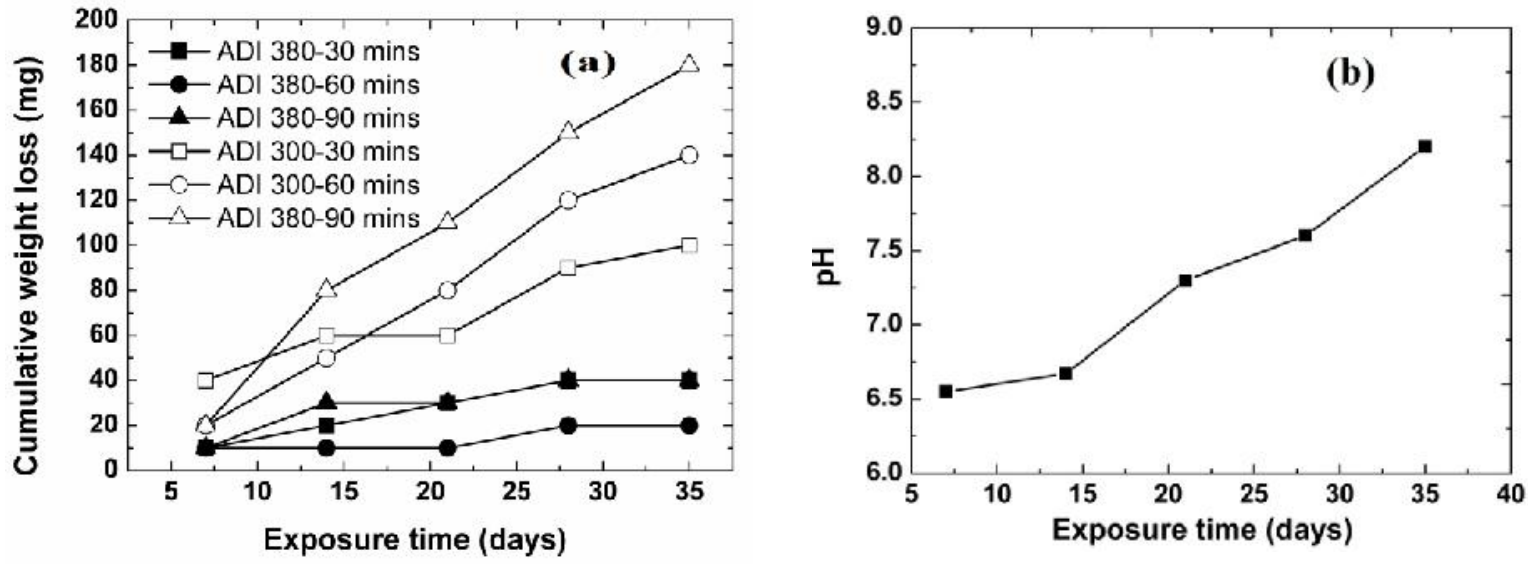

Figure 3(a) Cumulative weight losses versus exposure time for different samples, (b) Variation in $\mathrm{pH}$ of the iron ore slurry with time

The corrosion rates calculated from the weight loss at different $\mathrm{pH}$ levels of the iron ore slurry is presented in the Table 4. It was inferred from the results that the corrosion rates of the balls were strongly influenced by the $\mathrm{pH}$ of the iron ore slurry. The corrosion rate as a function of $\mathrm{pH}$ of the iron ore slurry for high temperature ADIs and low temperature ADIs are shown in Figure 4.

Corrosive wear during ore grinding occurs when a sliding takes place in a corrosive environment. There is a possibility that additional constituents could be introduced into the slurry from the grinding media balls and the chemical nature of the slurry keeps changing continuously in the mill and the slurry becomes corrosively active (Hebbar, 2011). In the absence of sliding (idle periods), the products of the corrosion will form a film on the surface, which will slow down or even arrest the corrosion. It is seen from Figure 4 that high temperature ADIs offered better corrosion resistance compared to low temperature ADIs.

Table 4 Corrosion rates from the weight loss data

\begin{tabular}{|c|c|c|c|c|c|c|c|}
\hline Exposure & \multirow{2}{*}{$\begin{array}{c}\mathrm{pH} \text { of } \\
\text { days }\end{array}$} & \multicolumn{3}{|c|}{ Austempered at 380 C } & \multicolumn{3}{c|}{ Austempered at 300 C } \\
\hline & slurry & $30 \mathrm{~min}$ & $60 \mathrm{~min}$ & $90 \mathrm{~min}$ & $30 \mathrm{~min}$ & $60 \mathrm{~min}$ & $90 \mathrm{~min}$ \\
\hline 7 & 6.55 & 5.41 & 9.98 & 4.15 & 15.9 & 7.25 & 5.45 \\
\hline 14 & 6.67 & 5.41 & 4.99 & 6.23 & 11.93 & 9.06 & 10.91 \\
\hline 21 & 7.3 & 5.3 & 3.33 & 4.15 & 7.95 & 9.66 & 10 \\
\hline 28 & 7.6 & 5.2 & 4.99 & 4.15 & 8.94 & 10.87 & 10.23 \\
\hline 35 & 8.2 & 5.3 & 1.99 & 3.32 & 7.95 & 10.15 & 9.82 \\
\hline
\end{tabular}

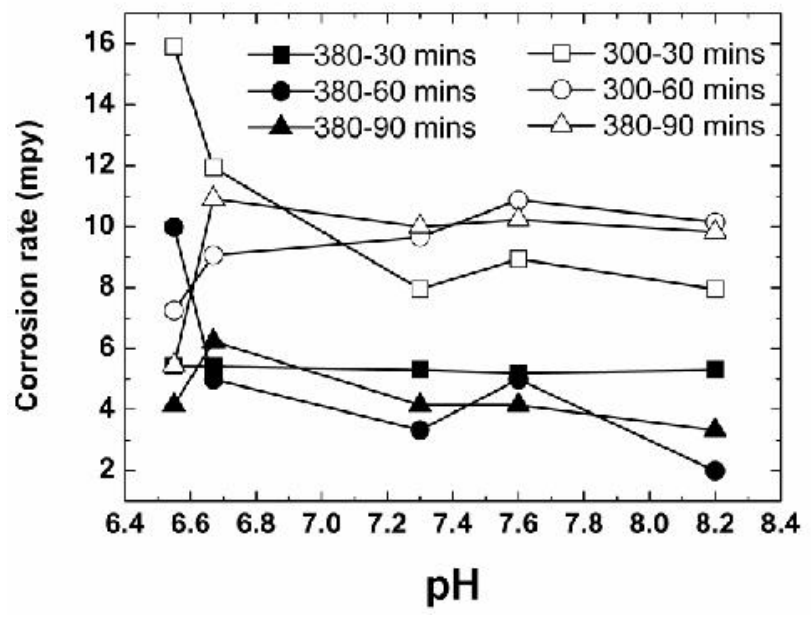

Figure 4 Variations in corrosion rate of (a) high temperature ADIs and (b) low temperature ADIs as a function of pH of the iron ore slurry 
Except for large variation of corrosion rate initially at low $\mathrm{pH}$ value, corrosion rate is more or less independent of the $\mathrm{pH}$ of the slurry and the microstructure developed at the two austempering temperatures. In general single phases such as ferrite, austenite and martensite perform better in corrosive environment than the two phase mixture such as pearlite, bainite and tempered martensite. The two phases in ADI (ferrite and retained austenite) could act as electrochemical cell and aid corrosion (Ailor, 1971). Since low temperatures ADIs have a fine structure, the two phases are so closely spaced that there are a number of such cells in a small area. Thus, the surface area available for corrosion is large in low temperature ADIs than the high temperature ADIs.

The corrosion of iron or carbon steels has a very complex dependence on the $\mathrm{pH}$ of the medium and it has been reported (Moiseeva and Rasheveskaya, 2002) that the corrosion rate increases with increase in $\mathrm{pH}$. The corrosion resistance of high temperature ADIs could be due to the formation of passive layer. The high silicon content in ADI materials is responsible for the development of a passive layer (casing) after certain time period of exposure to corrosive medium and which brought down the corrosion rate of the samples (Davies, 2001). It is also reported that higher austempering temperature improves corrosion resistance by making it nobler and decreasing corrosion rate (Hemanth, 2000).

\section{Conclusions}

The corrosion tests were carried out for the ADI samples with the iron ore slurry as the corrosion medium. The following conclusions were drawn from the present study.

1. Isothermal transformation of austenite at high austempering temperature lead to upper bainite and retained austenite while low austempering temperature consisted of lower bainite and retained austenite.

2. The content of retained austenite decreased with increase in austempering temperature and time while the ferrite content increased with increasing austempering temperature and time

3. The corrosion behaviors of ADI were strongly dependant on the $\mathrm{pH}$ of the slurry which keeps changing continuously as the mill is running.

4. The ADI austempered at higher austempering temperature showed better corrosion resistance than the ones austempered at lower temperature.

5. The complex nature of corrosion of ADI is influenced by contents of retained austenite, ferrite and the carbon content in a collective way.

\section{Acknowledgements}

The author (PM) gratefully acknowledges the faculties and lab technicians of the Department of Metallurgy \& Material Science, NIT-K for their support and assistance for completing this work as part of the M. Tech. thesis. Authors would also like to extend their gratitude towards Rev. Dr. Jose Kannampuzha, Principal, Amal Jyothi College of Engineering for his support and encouragement in publishing these results.

\section{References}

Afolabi A.S. 2011, Effect of austempering temperature and time on corrosion behaviour of ductile iron in chloride and acidic media, Anti Corrosion Methods and Materials, Vol.58, pp. 190-195

Ailor W.H. 1971, Handbook on corrosion testing and evaluation, John Wiley and Sons, Inc. London, pp 171-177

Arunima Banerjee,. Mitra P. K, Devi Prasad Chattopadhyay and Ashis Chowdhury, Effect of section thickness, $0.5 \% \mathrm{Cu}$ addition and different austempering temperatures on the microstructure and corrosion properties of ADI, (2013), Transactions of 61st Indian Foundry Congress, pp 1-3

Cheng-Hsun H., Ming-Lichen 2010, Corrosion behavior of nickel alloyed and austempered ductile irons in 3.5\% sodium chloride, Corrosion Science, Vol. 52, pp. 2945-2949

Cullity B.D. 1978, Elements of X-ray Diffraction, Addison-Wesley Publishing Company, MA, pp. 411-415

Davis J. R. 2001, Alloying: Understanding the Basics, ASM International, Ohio, pp.86-90.

Eric O., Brdaric T., Stojsavljevic N., Tonic M., Grahovac N., Duricic R., 2010, Determitation of processing Window for ADI materials alloyed with copper, Association of Metallurgical Engineers of Serbia, Vol. 16, pp. 91-102

Guesser W. L, Koda F, Martinez J. A. B. Da Silva C. H. 2012, Austempered Ductile Iron for Gears, SAE International, Sao Paulo, Vol 36, 305

Hebbar R. 2011, Investigation on grinding wear behaviour of austempered ductile iron as media material during comminution of iron ore in ball mills, Transactions of the Indian Institute of Metals, Vol. 64, pp.265-269.

Hemanth J. 2000, The solidification and corrosion behaviour of austempered chilled ductile iron, Journal of Materials Processing Technology, Vol 101, p159.

Jain S.K. 2001, Mineral Processing 2nd edition, CBS Publisher and distributor, New Delhi, pp. 102-105. 
Janjić M., Avdušinović H., Jurković Z., Bikić F., Savićević S. 2016, Influence of austempering heat treatment on mechanical and corrosion properties of ductile iron samples, Metalurgija, Vol 55, pp 325-328

Keough J. R, Hayrynen K. L. 2010, Applications of austempered gray iron,” AFS Transaction, AFS Proceedings, Schaumburg, IL USA, American Foundrymen Society, pp.1-15

Moiseeva L S, Rashevskaya N. S. 2002, Effect of ph value on corrosion behavior of steel in $\mathrm{CO}_{2}$,

Russian Journal of Applied Chemistry, Vol 75, 1625

Muthukumarasamy S, Sadiq Babu A. J and. Sesham S. 1992, High strength ductile irons-as cast bainitic ductile iron and austempered ductile iron, Indian Foundry Journal, pp.23-29.

Prasad Rao P.and Putatunda S. K. 2003, Investigations on the fracture toughness of austempered ductile iron alloyed with chromium, Materials Scince and Engineering, A, Vol. 349, No. 1-2, 136-149.

Prasanna N. D, Muralidhara M. K, Mohit Kumar Agarwal and Radhakrishna K. 2009, Mechanical properties and corrosion characteristics of IS400/12 grade ductile iron, Transactions of 67th Indian Foundry Congress, pp 89-95

Siddan J. B. 2014, Wear behavior of stepped austempered ductile iron balls in grinding iron ore, International Journal of Research in Engineering and Technology, Vol. 03, pp. 475-480.

Yelloji Rao M. K and . Natarajan K. A. 1991, Factors influencing ball wear and flotation with respect to ore grinding, Mineral Processing and Extractive Metallurgy Review, Vol. 7, pp. 137-173.

\section{Biographical notes}

Pooja M, Vijeesh V are Assistant Professors and K.G. Samuel is the Professor and Head, Department of Metallurgy, Amal Jyothi College of Engineering, Kanjirappally, Kerala, India under Mahatma Gandhi University, Kottayam, Kerala, India. Present work is part of the M.Tech. Thesis of M. Pooja done at the National Institute of Technology Karnataka, Surathkal, India

A. O. Surendranathan, K. R.Udupa are Professors at Department of Metallurgical and Materials Engineering, National Institute of Technology Karnataka, Surathkal, India

Received April 2016

Accepted July 2016

Final acceptance in revised form August 2016 